Bollobás, Enikő. "Versions of Triangular Desire in Hungarian Literature: Reading Sándor Márai and Péter Nádas." Hungarian Cultural Studies. e-Journal of the American Hungarian Educators Association, Volume 11 (2018) DOI:

\title{
Versions of Triangular Desire in Hungarian Literature: Reading Sándor Márai and Péter Nádas
}

\section{Enikő Bollobás}

\begin{abstract}
Two Hungarian authors, Sándor Márai and Péter Nádas, seem to have one thing in common: their attraction to triangular relationships. Written between 1935 and 1942 and portraying human relations in pre-World War II Hungary, Márai's two novels and one drama all turn on a very specific triangular structure between two close friends and the woman whom they both love(d). Now they conduct a painful tête-à-tête to decide on the final ownership (or simply fate) of the woman. Written in 1979 and portraying human relations in communist Hungary, Nádas's play has only two actors on stage, a woman of aristocratic descent and a young man, the son of a high-ranking communist official, the woman's long dead lover. This exchange between the two characters opens into an encounter of three, where the woman and the young man each use the other as a mediator to reach the third, the lover/father. Bollobás argues that the triangles displayed by the two authors represent two distinct types: the former is informed by fixed, hierarchical, subjectobject power relations, while the latter by fluid, non-hierarchical, subject-subject relations.
\end{abstract}

Keywords: Sándor Márai, Péter Nádas, triangles of desire, patriarchal triangles, intersubjective triangles

Biography: Enikő Bollobás (D.Litt.), Professor of American Literature at Eötvös Loránd University, Budapest, has published extensively on American and Hungarian literature. Her books include monographs on the poets Charles Olson and Emily Dickinson, two histories of American literature and two theoretical inquiries into performativity and subjectivity in literature, American and Hungarian alike. Her numerous essays have appeared in international scholarly journals, including American Quarterly, Arcade, Emily Dickinson Journal, Journal of Pragmatics, Language and Style, Modern Philology, Paideuma, and Word and Image. bollobas.eniko@ btk.elte.hu

Triangular structures of desire occur frequently in literature: one loves (desires) two, or two love (desire) one, simultaneously or consecutively. This seemingly simple formula reveals, when placed in the context of other triangles, unexpected complexities. In an attempt to explore these complexities, I examine triangular structures in two Hungarian authors, Sándor Márai and Péter Nádas, who share an intense preoccupation with triangles, whether in the form of a relationship between two close friends and a woman loved by both, or between two lovers and the son of one. Yet their triangles also show fundamental differences: while Márai's triangles are composed by rivalries between two persons in fixed positions, defined by hierarchy and domination, Nádas displays non-hierarchical and non-rival triangular relations with shiftingchanging positions. 
Bollobás, Enikő. "Versions of Triangular Desire in Hungarian Literature: Reading Sándor Márai and Péter Nádas." Hungarian Cultural Studies. e-Journal of the American Hungarian Educators Association, Volume 11 (2018) DOI: 10.5195/ahea.2018.321

\section{Márai's Patriarchal Triangles in Two Novels and a Play}

Hungarian fiction writer and dramatist Sándor Márai (1900-1989) devoted a particular attention to triangles. Three such works - of which only the last has been translated into English — stand out: written during the short period between 1935 and 1942, Válás Budán ['Divorce in Buda'] (1935), Kaland ['Adventure'] (1940), and A gyertyák csonkig égnek ['Embers'] (1942) all turn on a most conspicuous triangle structure.

A novel weighed down by dramatic elements, Divorce in Buda presents a painful head-tohead between two old friends, the doctor Imre Greiner and the judge Kristóf Kömíves. The night before the divorce trial of Greiner and Anna is supposed to take place, Greiner shows up at his friend's home to tell him that Kömíves would not preside over the trial the next day since Anna had committed suicide a few hours previously. She took a deadly dose of sleeping pills most probably because she had been tormented by the fact that by always loving, at heart, Kömíves and not Greiner, she had provided the legal grounds for divorce: infidelity. What Greiner wants to know is whether Anna's hidden devotion, surfacing in her dreams only, was reciprocated: has Anna been appearing in Kőmíves's dreams, moreover, has he ever seen Anna's face while making love to another woman? In other words, Greiner is really interested in the other man's feelings, inadmissible desires, and sexual subconscious. Their dramatic confrontation is to test the rivalry of the two men, while the woman - left lying dead in her home - becomes irrelevant, as if put into parentheses in the story of her own life.

The play Adventure reveals an even more obvious triangle structure. Here we also have a married couple, the medical professor Péter Kádár and his wife, Anna, and another man, Kádár's subordinate in the clinic, Dr. Zoltán, who has been romantically involved with Anna. Kádár's life is turned upside down by news he receives one after the other: that the lovers are ready to leave him and that Anna has lung cancer, with no more than six months to live. Kádár now devises an intricate plan: not only does he let go of Anna, he also works out every detail of their "adventure": he sends them to the Swiss sanatorium of his own choice, covering all their expenses, and specifically "orders" Zoltán to follow his instructions to the last point. Clearly, the dramatic events take place between the two rival men, of which the power figure, Kádár, wants to control the others involved. All the while, the woman lies in her bedroom, sedated, terminally ill, misled. Kádár does not allow her to understand the gravity of her illness, always cutting her short when she demands to know; he similarly silences her when she wants to give him the reasons for leaving him. Denied a voice, her subjectivity is also denied; for, as we know from Émile Benveniste, language and subjectivity are inextricably connected: it is language alone [that] establishes the concept of 'ego' in reality; “'[e]go' is he who says 'ego" (Benveniste 1986: 729; emphasis in original). As such, the woman once again drops out of the triangular structure, turning it into a binary relationship between two competing men.

The best-known piece of the three works as well as the only one translated into English, Embers presents, once again, a painful exchange between two men who had once been best friends. The two men are in their seventies in the novel's narrative present, having carried the heavy burden of the past for forty-one years, ever since Konrád conducted a passionate liaison with Krisztina, Henrik's wife. The men have not seen each other since, but now Konrád initiates their final encounter, which Henrik succumbs to, knowing very well that the three of them are "as inextricably attached as crystals in the law of physics" (Márai 2001: 250) [hármunknak olyan közünk van egymáshoz, mint a kristályoknak egy mértani törvény képletén belül; Márai 1990: 119], as Henrik puts it. Forty-one years before, upon learning about the affair between Konrád 
Bollobás, Enikő. "Versions of Triangular Desire in Hungarian Literature: Reading Sándor Márai and Péter Nádas." Hungarian Cultural Studies. e-Journal of the American Hungarian Educators Association, Volume 11 (2018) DOI: 10.5195/ahea.2018.321

and Krisztina, Henrik immediately cut out the woman from their triangular relationship, punishing her by never speaking to her again. With no other outlet to be heard, she left a secret diary for her husband as a speaking legacy, which Henrik has never opened; now he throws it into the fire before Konrád, irrevocably silencing the woman three decades after her death. With the woman deleted from this triangle, what we have left is, once again, the rivalry between the two men. Henrik is less concerned with the woman's emotions or her infidelity than with the friend's alleged betrayal of him. As he says, "Only one thing was incomprehensible: that you had committed a sin against me" (Márai 2001: 134) [Csak egyet nem tudtam megmagyarázni: azt, hogy ellenem vétkeztél. Ezzt nem értettem. Erre nem volt mentség; Márai 1990: 68]. Once again, unable to interpret their love affair as anything but his competitor's attempt to defeat him, the dominant male deprives his rival of even the memory of their love. And, once again, as the woman becomes silenced and excluded, the triangular structure deflates, flattening into a binary connection between two male rivals.

Already the foregoing short plot summaries reveal that Márai came up with a peculiar triangular structure. These triangles are unlike the usual love triangles in which one man loves two women or two men desire one woman and which, because agency is typically attached to the men and can therefore be rightly called patriarchal. No less patriarchal, Márai's triangles are nevertheless fundamentally different in the sense that they do not model permanent triangular relations but, with the woman dropping out from these structures, turn into binary structures with two poles only, taken by the two male rivals.

Now I would like to take a short detour to the somewhat abstract field of patriarchy theory as practiced by Claude Lévi-Strauss, René Girard, and some feminist thinkers to show that triangular structures are systemically tied to patriarchy. Lévi-Strauss pointed out that the true aim of exogamy in primitive societies was not incest prohibition but rather the extension of kinship and the consolidation of existing social institutions; the real mission of exogamous marriages, he claims, was to establish, by the transfer of women, new kinship relations, and thereby alliance relations, between the male members of the tribe (Lévi-Strauss 1969: 46). As gifts exchanged in this transaction, women become objectified and reified. Girard highlights a more personal aspect of patriarchy when he proposes, based on his reading of European fiction, that a third person is regularly present when desire is born between two (Girard 1972: 21). Of the two male subjects who own desire, one is the desiring subject, while the other the rival subject; between them there is the desired woman, who is not only the object of their desires but is also, as Girard puts it, "the mediator of desire" (2). In such a triangular relationship woman can never be subject in the sense that her "value" does not stem from her own self but from the "price" the rival man would be willing to pay for her ownership. The most important trait of triangular desire is, Girard insists, that desire does not stem from the subject but from the object, and is produced, moreover, through the rivalry of the subjects, of "two competing desires" (7). Feminist historians and philosophers who describe gendered power relations are even more explicit when discussing male alliance and female subjection within patriarchy. Gayle Rubin, Heidi Hartman, and Eve Kosofsky Sedgwick list among the systemic characteristics of patriarchy the exchange women as merchandise, the ensuing solidarity between men and the subordination of women, the strong homosocial bonds between rival men (often stronger than the erotic bond between man and woman), and the overall gender asymmetry resulting from male interdependence (see Rubin 1975/1997, Hartman 1981, and Sedgwick 1985). 
Bollobás, Enikő. "Versions of Triangular Desire in Hungarian Literature: Reading Sándor Márai and Péter Nádas." Hungarian Cultural Studies. e-Journal of the American Hungarian Educators Association, Volume 11 (2018) DOI: 10.5195/ahea.2018.321

The above theoretical claims can be applied specifically to the Márai texts. In all works women are "transferred" in order that the men widen their alliances: Greiner and Kömíves establish their bond through Greiner's wife, Anna (Divorce in Buda); Kádár and Zoltán through Kádár's wife, Anna (Adventure); and, most of all, Henrik and Konrád through Henrik's wife, Krisztina (Embers). In each case, the men compete for the ownership of the same woman acting as the mediator of their desire. Since women mediate between the men by collecting, as objects, men's desire, I consider women in such patriarchal situations as object-mediators. Rivalry is especially eminent in Adventure and Embers, where the dominant parties of the male pairs, Kádár and Henrik, repeatedly proclaim their superiority, being certain that their rivals, Zoltán and Konrád, tried to win over the wives of their friends only to beat them in the competition. That is, the dominant men take it for granted that the homosocial bond between the men supersedes the desire for woman. The men take their rivals more seriously than their wives: Greiner is more curious about his rival's feelings than about those of his dead wife (Divorce in Buda); Kádár conducts business only with Zoltán, not with his wife (Adventure); Henrik demands answers from Konrád, while he refuses to read the dead woman's diary (Embers). Moreover, the value of the woman derives not from herself but from the fact that the rival man also desires her: especially in Adventure and Embers are the two men attached to the woman because she was desired by the other man. In other words, the men only view the other man as subject, taking the woman as object only, who mediates between them. Yet not even her mediation is allowed to be an act of agency (which it could be, as we shall see in the Nádas play): she is made a literal patient (Adventure) or is ultimately passivized in death (Divorce in Buda, Embers). We can also draw the general conclusion, applicable to all of Márai's triangles, that the positions are fixed as well as gendered: two men, acting as subjects or agents, solidify their bond through a woman, object or patient, who mediates between them. Moreover, their triangles are asymmetrical in terms of both power asymmetry between the two men and power asymmetry between man and woman. The core relationships deflate each triangle into a binary relationship between the competing friends or rivals who try either to subordinate or exclude the woman. So the question arises, if the trio comes down to a duo, can these structures be still considered triangles? Before answering this question, I will discuss another triangular structure, the one articulated by Nádas, which will help set the two types apart.

\section{Nádas's Intersubjective Triangle in one Play}

In my analysis of Péter Nádas, I will focus on one work only, Találkozás ['Encounter'] (1979), ${ }^{1}$ a two-character, single-set drama displaying an emotional liaison of three people variously attached to one another. The events on the stage take place in the flat of Mária, a woman now in her fifties. We are in the 1960s or 1970s, deep in communist Hungary slowly resuscitating from the trauma of Hungarian Stalinism of the 1950s, the revolution of 1956, and

\footnotetext{
${ }^{1}$ The play has been translated into English by Judith Sollosy, but only a part has been published (Péter Nádas, Encounter, trans. Judith Sollosy, Asymptote [October 2013], http://www.asymptotejournal.com/drama/peter-nadasencounter/). Citations marked as "Nádas MS" refer to the unpublished manuscript version of the full text Ms. Sollosy has graciously shared with me, and are given with her kind permission.
} 
Bollobás, Enikő. "Versions of Triangular Desire in Hungarian Literature: Reading Sándor Márai and Péter Nádas." Hungarian Cultural Studies. e-Journal of the American Hungarian Educators Association, Volume 11 (2018) DOI: 10.5195/ahea.2018.321

post-revolutionary Kádárist terror lasting well into the 1960s. Mária is a woman of aristocratic descent, a countess, persecuted in the 1950s and now stigmatized and marginalized; hence her extreme poverty shown in her less than modest tiny flat. Soon her guest, the Young Man whose name we never learn, arrives, and they begin their slow and painful conversation.

The son of her long dead lover, the Young Man initiated the meeting in order to learn about his father: "I just want to know what happened. To know ... I want to hear about my father," he admits (Nádas MS: 13) [Én csak tudni szeretném, mi volt. Tudni...Az apámról akarok hallani; Nádas 2001: 114-5]. Theirs was a peculiar liaison, Mária recalls, back in the early 1950s, when they had met accidentally, as their paths crossed every morning as they cut through a small square in opposite directions. They had their clandestine (and always wordless) rendezvous in a room with whitewashed walls resembling prison cells. They never spoke about themselves, never revealed anything about their lives; theirs was the passion of two lovers without names or identities. In such a relationship, Mária had no way of knowing that the man was a high-ranking officer in the ÁVH, the Hungarian version of the Soviet NKVD, which was communism's dreaded repressive agency known for its brutality and terror from 1948 to the 1956 Hungarian Revolution. Only a few months later, when she was taken by the police (most probably to ÁVH Headquarters, 60 Andrássy Avenue), as she regularly was, did she come face to face with this most powerful man, here presiding over one of her many beatings. Now she recognizes that their rendezvous and the beatings regularly took place in the same establishment: "We're in the same house. The house hurts" (Nádas MS 67) [Ugyanabban a házban vagyunk. Fáj a ház; Nádas 2001: 166]. After the lovers' meeting in the interrogation room, the man's vigor begins to fade, his health deteriorates, he loses weight, and his once healthy complexion turns pallid and sallow: "He had grown thin, though not pale, just some yellow skin on an unfamiliar face" (Nádas MS: 71) [Sovány lett, nem volt sápadt, hanem egy idegen arcon sárga bör; Nádas 2001: 170]. Confronted by the fact that he loves the same (aristocratic) woman whose beatings he had perhaps ordered, but certainly witnessed, he is beset by a severe crisis of conscience. Emotionally crippled, he commits suicide by shooting his revolver into his mouth right in front of the woman. As such, he becomes the victim of the institutional power he served, ending not only his life, but also the life of the woman who loved him: "He put an end to my life" (Nádas MS: 71) [Befejezte az életem; Nádas 2001: 170], she admits.

While the encounter between the woman and the Young Man make up the actual events on the stage, past events are evoked by the characters remembering the dead lover/father. This recalling of memories opens the encounter between the two characters into an encounter of three, in which the woman and the Young Man use the other as a mediator to reach the third, the lover/father. Constructed of acts of sense-making and self-transformation, the play's plot hinges on the interlocking encounters between the two living persons and the dead one, unfolding as the interplay of actual and remembered events. The Young Man admits that he decided to seek out the woman because he wanted to hear someone talk-lovingly, perhaps - about his father of whom he, a very small child at the time he died, had no actual memories. For the first several minutes he is uneasy, listening to Mária rather than joining the conversation. In the eyes of the woman, the son seems to have the body of the father; as he says, "I wear my father's body" (Nádas MS: 55) [Viselem az apám testét; Nádas 2001: 152]; this identification triggers the woman into telling her stories. She takes pleasure in narrating the story of her life ('I'm remembering for you" [Nádas MS: 12] [magának emlékezem; Nádas 2001: 112], she says), which, we soon learn, cleanses her for the final encounter with death. Sometimes she gets 
Bollobás, Enikő. "Versions of Triangular Desire in Hungarian Literature: Reading Sándor Márai and Péter Nádas." Hungarian Cultural Studies. e-Journal of the American Hungarian Educators Association, Volume 11 (2018) DOI: 10.5195/ahea.2018.321

confused, uncertain of whether it is the past or the present she is recalling, or whether it is the father or the son she is talking with: "These times get mixed up a little" (Nádas MS: 49) [Kicsit összekeverednek ezek az idök; Nádas 2001: 148], she says, feeling disoriented. Soon the Young Man opens up and talks more and more. Seeing that the woman really listens, he feels encouraged to tell his own stories. Being recognized by the other, and registering this recognition, he takes joy in self-presence: "I'm all here" (Nádas MS: 20) [Nagyon itt vagyok; Nádas 2001: 122].

Having told her story to her lover's son brings relief and a sense of freedom for Mária, which she ultimately shares with the young man in a most peculiar way. Having broken her silence which had kept her prisoner, and having passed on the secret to the son, she feels liberated from the past: "You can't imagine how good it is talking about it. Just plain good. I'll be free at last" (Nádas 2001: 50) [El sem tudja képzelni, milyen jó mesélni. Egyszerüen jó mesélni. Megszabadulok; Nádas MS: 149]. Her forgiveness finds its form in an unexpected act she performs on the Young Man's body as if on the father's: a ritual washing of the dead. After slowly taking off the clothes of the Young Man sitting and then standing over a small washbasin, she starts to wash him slowly and methodically, all the while talking, evoking, in minute details, her final encounter with his father, the one ending in his suicide. The Young Man remains lifeless during the whole ritual: motionless, apathetic, staring into space. Mária acts as agent initiating and performing the ritual, as well as an agent who actively and willingly mediates; as such, she is subject-mediator, one who mediates as subject and between subjects. In this capacity, she brings about the purification of all involved through the ceremonial act of washing the young man's body. First, as a woman bathing the dead, she cleanses her dead lover of his sins, both political (he was a high-level officer of ÁVH) and ethical-religious (he committed suicide), granting him peace. Second, she purifies the bond between father and son, allowing the son to relate physically to the dead father, to reach, through his own body, a lived recognition with the father he always resisted. Third, after appropriating to herself the status of the wife, who in several religions has the right to wash the body of her husband, the woman prepares her own transition from life to death. Her purification ceremony is subsequently performed as a religious ritual, bringing about yet another encounter: that between life and death. Having invoked and granted full forgiveness to her lover through the narrating of their story to his son and the ritual bathing of the latter, she finally drinks her red wine mixed with a poisonous white powder that she had already prepared before the son's arrival. Thus, she allowed herself to let go of life, "disappearing slowly into the white space" (Nádas MS: 72) [lassan távolodik a fehér térben; Nádas 2001: 171]. She goes gracefully and in peace, ready for the hoped-for final encounter with her long-dead lover.

Recognitions, or subject-subject encounters, play a crucial role in the play because they contradict our readerly expectations concerning communism and patriarchy. Communism allowed for no shared world between the countess and the secret police officer: communist oppression had created so-called "class enemies" out of them, making sure they would never meet (outside of police interrogations and beatings). As to the son's relationship with his father, their worlds were similarly disjunctive: not only because as a small child the son hardly knew his father but also because the son, not being able to accept his father's crimes as an ÁVH officer, turned against him. It is not indicated in the play how much the son knew about the father's specific crimes (such specifics are little known even today), but he seems to have known enough to refuse to build an emotional rapport with an ÁVH officer, even if he was his father. Similarly, 
Bollobás, Enikő. "Versions of Triangular Desire in Hungarian Literature: Reading Sándor Márai and Péter Nádas." Hungarian Cultural Studies. e-Journal of the American Hungarian Educators Association, Volume 11 (2018) DOI: 10.5195/ahea.2018.321

patriarchal assumptions had to be resisted by both Mária and the Young Man in order to enter into a meaningful encounter with each other. For patriarchal mentalities would make the husband's lover invisible for the man's family, non-existent, to be ignored even decades after the affair. She therefore needs determination to receive the son, while the Young Man must have also given up his resentment towards his father's mistress. In other words, both the woman and the Young Man must go against the norms dictated by both communism and patriarchy in order to recognize the Other in a subject-subject encounter. Moreover, the players in Nádas's triangle resist not only the political norms of communism creating disjunctive worlds for "class enemies" and the patriarchal norms demanding that an extra-marital affair remain taboo for family members, but also the normative patriarchal scenario of two male subjects competing for the mediating woman as the prize and emblem of domination (as it appears in the works of Márai). Here we have on the stage a man and a woman who both desire an absent third. Here at one point or another, all three characters act — or are remembered as acting (as the father/lover) — as subjects (desiring), objects (desired), and mediators (passive object-mediators and active subjectmediators). Therefore, I read Nádas's triangle as intersubjective, based on shifting-moving subject-object and subject-subject relations.

As opposed to the fixed and gendered positions of the Márai plots, the positions in this triangle between woman, lover/father, and son seem to shift easily, allowing each character, independent of their gender, to take up subject and object positions alike. Let's see how this is done in each relation and for each character. As to the father, his lost subjectivity (lost when he recognized his object position in the political machinery) is restored, decades after his death, by the narrating and mediating woman and the son lending his body to the father in the ceremonial washing. The father's memory acts as a passive object-mediator between his son and the woman, while the son, gaining agency through initiating the meeting with the woman, is a subjectmediator between the two lovers. Mária offers herself as a medium by inviting the lover/father to speak through her. By narrating past events to the son, she performs a face-giving ceremony, thereby granting subjectivity to the man who had "lost face" both metaphorically and physically: metaphorically before his son for his political crimes and physically when he shot himself in the mouth. That is, once again Mária acts as a subject or agent, who in turn also confers subjectivity to the two men.

In the play's emotional climax of washing, the experience of tactility informs the most intense intersubjective relation. While it is meant to reach out to the dead father, the woman's physical touch transforms the young man. By a manumission of sorts, Mária performs the act of vindication, liberating the person who, as the metaphorical slave of an oppressive state apparatus, was stripped of his freedom, both political and emotional. This is also part of the closure she brings about, both for herself and the Young Man. Ultimately, it is these recognitions and encounters that turn the play evolving through intertwining narratives into what the author called "the most beautiful love story in the world" (Nádas MS: 57) [a világ legszebb szerelmes története; Nádas 2001: 155].

In my essay I have differentiated between two pivotal triangular structures: patriarchal (characterized by hierarchy, fixed positions, and rivalry for domination) and intersubjective (characterized by non-hierarchy, shifting positions, and reciprocity/interchangeability). The primary parameters along which the two types can be set apart are fixity vs. fluidity of gendered subject/object roles. On the one hand, we have patriarchal triangles characterized by being binary relations, whether we consider rival relations or erotic relations. Positions are fixed: the 
Bollobás, Enikő. "Versions of Triangular Desire in Hungarian Literature: Reading Sándor Márai and Péter Nádas." Hungarian Cultural Studies. e-Journal of the American Hungarian Educators Association, Volume 11 (2018) DOI: 10.5195/ahea.2018.321

dominant person insists on his domination over both his rival and the desired woman. Positions are also fixed in terms of gender: men always occupy subject positions, while women take object or object-mediator positions. The relations are hierarchical and one-directional subject-object relations. On the other hand, intersubjective triangles comprise relations with changeable positions among desiring subjects, desired objects, and mediators (object-mediators and subjectmediators alternatively). Positions are also gendered variably: men and women can equally take subject and object positions, or positions of the desiring, desired, or mediator. Desire can be owned by woman as much as man can be the object of desire. These intersubjective relations are non-hierarchical, based on the recognition of the Other as subject.

I do not wish to claim that the two types of triangular structures, patriarchal vs. intersubjective, are mutually exclusive; rather, I posit the two as meaningful formations identifiable among the structural elements of triangular relations. To capture the nature of this relationship, I adopt the succinct observation regarding Freud's heimlich-unheimlich ['familiaruncanny'] relationship given by Pál Hegyi, who points out that the peculiarity of this relationship lies in the fact that, obeying the compulsion to repeat infinitely, the unheimlich contains its own opposite, the heimlich (Hegyi 2017: 279). By the same token, intersubjective triangles can be said to contain, in an uncanny manner, their own opposite, the patriarchal —as if in obeisance of some impulse to infinitely repeat one normative schema within a supposedly dichotomous other. Following Hegyi's diagram (279), then, this is how I visualize the interconnectedness of patriarchal and intersubjective triangles:

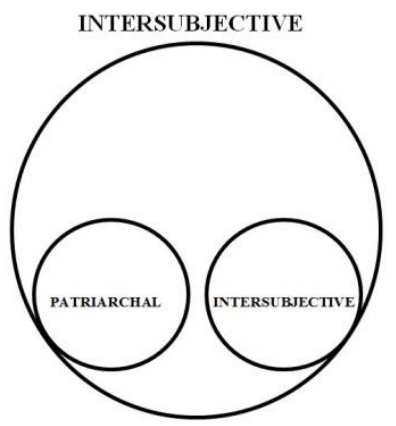

Finally, to answer the question I posed earlier in my essay, I believe that, given the fact that patriarchal triangles are made up of binary relations with fixed positions between rivals who compete for domination and who basically strive to exclude women (or at least make them irrelevant), these only look like triangles but do not function as such. Only intersubjective triangles are truly triangular, those based in subject-subject relations, since here the selves mutually engage with each other, experiencing other subjects from fluid and changeable positions. And this can happen even if the intersubjective structure contains, in a most unheimlich manner, patriarchal relations.

\section{Works Cited}

Benveniste, Émile. 1986. "Subjectivity in Language.” Critical Theory Since 1965. Ed. Hazard Adams, Leroy Searle. Tallahassee: UP of Florida: 728-732. 
Bollobás, Enikő. "Versions of Triangular Desire in Hungarian Literature: Reading Sándor Márai and Péter Nádas." Hungarian Cultural Studies. e-Journal of the American Hungarian Educators Association, Volume 11 (2018) DOI: 10.5195/ahea.2018.321

Girard, René. 1972. Deceit, Desire, and the Novel: Self and Other in Literary Structure. Trans. Yvonne Freccero. Baltimore: Johns Hopkins UP.

Hartman, Heidi. 1981. "The Unhappy Marriage of Marxism and Feminism: Towards a More Progressive Union." Women and Revolution - A Discussion of the Unhappy Marriage of Marxism and Feminism. Ed. Lydia Sargent. Boston: South End Press: 1-41.

Hegyi, Pál. 2017. "The Weird - Kísérteties mémek és hátborzongató mesék az elmondhatatlan történetröl” ['The Weird - Goulish Memes and Gruesome Tales about the Unsayable Story']. Literatura XLIII/4: 274-283.

Lévi-Strauss, Claude. 1969. The Elementary Structures of Kinship. Trans. James Hark. Boston: Beacon P.

Márai, Sándor. 1990. A gyertyák csonkig égnek ['Embers']. Budapest: Akadémiai Kiadó / Helikon Kiadó.

Márai, Sándor. 2001. Embers. Trans. Carol Brown Janeway. London: Penguin.

Nádas, Péter. 2001. “Találkozás” ['Encounter’]. Drámák. Pécs: Jelenkor, 95-173.

Nádas, Péter. MS. Encounter. Trans. Judith Sollosy. Manuscript. Cited with the kind permission of the Translator.

Rubin, Gayle. 1975/1997. "The Traffic in Women: Notes Towards a 'Political Economy' of Sex." The Second Wave: A Reader in Feminist Theory. Ed. Linda Nicholson. New York: Routledge: 27-62.

Sedgwick, Eve Kosofsky. 1985. Between Men—English Literature and Male Homosocial Desire. New York: Columbia UP. 